\title{
BIOINOCULANTS FOR COIR RETTING
}

by

\author{
A. N. Ravindranath \& U. S. Sarma ${ }^{1}$
}

\begin{abstract}
The mesocarp of the coconut or its husk is the source of coir. Coir fibre has several potential end uses like for the manufacture of various coir products predominantly coir floor coverings, yarn, rope, rubberized coir and latest as geotextile material. Coir is extracted from the coconut husk which is subjected to steeping in saline backwaters for six to nine months. This prolonged period of steeping is disadvantageous on economic considerations and also deprives the coir industry of sufficient raw material for the product sector. The treatment of selected strains of phenol degrading bacterial cultures on to husks immersed for retting is reported to reduce the period of retting to some extent 3. This paper reports the findings of a field study on the treatment of selected strains of bacteria on one lakh husks steeped for retting. Samples of husks drawn out after three months of steeping were observed to be fully retted and yielded fibre suitable for spinning superior quality coir yarn.
\end{abstract}

\section{INTRODUCTION}

The saline backwaters in Kerala on the South West Coast of India provide natural facilities for coconut husk retting. This has led to the establishment of the coir industry which is the source of income for a major section of the rural population here. It also fetches an export earning of over 100 crores, rupees for India. The export figures for 1993-94 was approximately 130 crores. 'White fibre' or retted coir is ideal for spinning yarn which in turn is utilized for the manufacture of products. The fibre is extracted from mature coconut husks which are transported to the retting site by road and waterways. Green husks are separated from dry husks, and bundled into lots between 8000 to 1000 in coir nets. The bundles are afloat in the saline waters until they get fully soaked, become heavy and submerge under water. The retting period ranges between six to nine months by traditional methods. During this period, by microbial action, the husk constituents holding the fibre 'in situ' are degraded. This leads to the loosening of the fibres which can be extracted by subjecting to a beating treatment with wooden bars. Alternate to the retting process, coir may also be extracted by mechanical processing to yield a comparatively inferior quality fibre brown fibre7. This brown fibre is mainly extracted from dry and semidry husks and finds end uses, in the manufacture of rubberized coir, upholstery fittings and coir needled felt. Irrespective of its extraction method, coir has remarkable stretching properties besides possessing high resistance to attack from microorganisms because of its impervious nature. The property of resistance to decay in salt water makes coir most suitable for different marine operations.

The realisation of the deleterious effects of synthetics in the Iong run to man and environment has increased the demand for coir. Coir is a versatile hard fibre of natural origin and its products, have attained a foothold in most countries, in the international market. With its, increasing demand in both the internal market in India as well as overseas, it is the need of the hour to ensure an uninterrupted supply of the coir fibre for the product sector of the coir industry.

A major step towards this direction is reducing the retting period for coconut husks from 6-10 months to the least possible simultaneously maintaining the quality of the extracted. fibre. The phenomenon of retting essentially consists of three stages - a physical, a biological and a mechanical

\footnotetext{
${ }^{1}$ Senior Scientific Officer, Central Coir Research Institute, Kalavoor, South India.
} 
stage. In the first stage the tissues of the binding matter within the husks swell under water at the same time air is expelled from the tissues and a number of organic substances mainly polyphenols and carbohydrates, glucosides, nitrogen compounds and colouring matter are released into the ambient waters. It has been reported 2 that the presence of polyphenols leached out during the soaking of the coconut husk results in the inhibition of survival and proliferation of the microorganisms responsible for bringing about retting. It was envisaged that the toxicity of the polyphenols could be removed by seeding of selected strains of phenol degrading bacteria. The biochemical changes which take place during retting mainly consist of reduction in the pectin, polyphenols, pentosans and fat and resin contents in the coconut husk resulting in the proliferation of a great variety of microfloral. There is comparatively little change in the lignin and cellulose indicating that the lignocellulosic complexes present in the coconut husk are not attacked by the microorganisms (Table 1).

\section{METHODOLOGY}

The present study was conducted at a retting site at Kayamkulam which is about $120 \mathrm{kms}$ from Thiruvananthapuram, the capital of Kerala. In the experimental work mature husks were bundled into lots between 8000 to 10,000 in twelve lots and steeped for retting. Two lots with the same conditions were steeped at a different site and was maintained as the untreated control lot. T'he retting yard had access to tidal influence of the Kayamkulam estuary of the Arabian Sea.

The phenol degrading strains of bacteria taken up for this study were $C B M B C B M D$ and $C B P D$ The first two cultures are species belonging to the Actinomycetes genera and are essentially Gram negative bacteria, bearing flagella and have been isolated from soil by adding 0.05-0.1\% phenol to, a mineral salts solution. The third culture belongs to, the genus Pseudomonas whose metabolic faculties are important for the mineralisation of organic matter. This third culture has been isolated from coir ret liquor by enrichment with phenols as the only carbon source. It is also Gram negative, rod shaped and strictly aerobic bearing flagella and attacks phenol. For the present study the three cultures were mass cultured under laboratory conditions, on nutrient medium. The inoculated medium was incubated for seven days and the rich growth of cells on nutrient medium was transported in surface steril ized carriers in the field site. The biomass was inoculated on to, the husk lots, steeped for retting at 5 different points. The inoculum was added @ 4 liters for 5,000 husks and the treatment was, repeated after one month of inoculation. Samples of husk were drawn out at fortnightly intervals from both the treated lot of husks as, well as the untreated control lot for examining the progress of retting. The environmental parameters of water such as temperature, $\mathrm{pH}$ and salinity were also noted.

\section{RESULTS AND DISCUSSIONS}

With the immersion of the husks in water the retting commences and its, completion is evidenced by the husks becoming comparatively soft and loosened. The exocarp can be effortlessly peeled off and the drenched husk can be squeezed as a result of which already loosened fibres can be further separated by either beating with wood mallets, or by machine combing. Samples of husks were drawn out at random after three months simultaneously from both the treated and untreated control lots of coconut husks steeped for retting. The observations were that whereas, the husks from the treated lots were observed to, have completed retting those from the control lot exhibited incomplete retting with a hard nature and could not be squeezed out easily by the rinsing action. The fibre extracted out from the husks drawn from treated lot was observed to, be of a brighter colour with little pith content. There was a high pith content in the fibre extracted from the untreated lot of husks. Thus the period of retting coconut husks which by traditional methods takes 6-9 months could be brought down to three months to yield fibre of a fine quality. The environmental parameters were analysed and the observations were that the temperature of water during the period of study ranged between $25-28^{\circ}$. The $\mathrm{pH}$ was noted to fall between $6-8$ and the salinity ranged between $23 \%$ to $25 \%$. 


\section{CONCLUSIONS}

The observations indicated that treatment of husks with bioinoculants can reduce the retting period for coconut husks and yield coir fibre of superior quality. This process therefore has a potential to benefit the coir inclustry in the following respects:

1. Increasing the availability of the raw material for the inclustry.

2. Reduce the cost of production by saving the interest on the capital invested towards the cost of husks.

3. Increase the husk potential, for the coir industry.

\section{RECOMMENDATIONS}

In order to extend the technology to the coir industry, it is recommended that efforts be made to popularize the bioinoculant treatment method. Exploring the possibil ity of identification of strains with greater potentials for reducing the retting period for coconut husks and development of suitable formulations for field use are areas for further research.

\section{ACKNOWLEDGMENTS}

The authors are grateftil to Shri K. George Joseph, I.A.S., Chairman, Coir Board and Ms. Minnie Mathew, I.A.S. Secretary, Coir Board for their keen interest and encouragements on the subject. The authors would also like to extend their gratitude to Shri. M.S. Thampan of Kayamkulam for providing ail the facilities at the field level for the study.

\section{REFERENCES}

VARRIER, N. S. and MOUDGILL, 1947. Analysis of Coconut

BHAT,J.V. and NAMBUTHIRI.1971.The Uniquity of Coir Retting. J. Scient. Ind. Res. Vol. $30-17-28$

ANITA DAS RAVINDRANATH, 1991. Processing of Coir - A Biological Approach to Retting of Coconut husks. CORD Vol. VII NO. 2 July 1991

ANITA DAS RAVINDRANATH, 1992. Application of Biotechnology in the Extraction of 'Golden Coir'. Paper presented at India's Third International Exhibition and Conference on Biotechnology 28-31st October 1992, Bangalore, India. 
Table 1. Lignocellulistic Complexess Present in Coconut Husk

\begin{tabular}{|c|c|c|c|c|c|c|}
\hline \multicolumn{7}{|c|}{ Sampel Number } \\
\hline Sample & Raw Husk & 1 & 2 & 3 & 4 & 5 \\
\hline Ash \% & 6.23 & 5.12 & 3.59 & 3.09 & 3.07 & 2.96 \\
\hline Fats \& Resins \% & 5.46 & 5.34 & 1.91 & 1.86 & 1.21 & 1.20 \\
\hline Legnins \% & 38.40 & 37.77 & 40.19 & 41.26 & 41.78 & 41.87 \\
\hline Cellulose \% & 35.94 & 38.99 & 41.56 & 40.94 & 41.23 & 42.87 \\
\hline Pentosan \% & 13.23 & 12.19 & 12.58 & 12.71 & 12.59 & 12.25 \\
\hline Pectins $\%$ & 0.74 & 0.52 & 0.19 & 0.16 & 1.11 & Traces \\
\hline
\end{tabular}

Table 2. Export of Coir and Coir Products from India (April to March)

\begin{tabular}{|l|r|r|r|r|}
\hline \multirow{2}{*}{ Item } & \multicolumn{2}{|c|}{$1993-1994$} & \multicolumn{2}{c|}{$1992-1993$} \\
\cline { 2 - 5 } & \multicolumn{1}{|c|}{$\begin{array}{c}\text { Quantity } \\
\text { (Tons) }\end{array}$} & $\begin{array}{c}\text { Value } \\
\text { (Rs Lakhs) }\end{array}$ & \multicolumn{1}{c|}{$\begin{array}{c}\text { Quantity } \\
\text { (Tons) }\end{array}$} & $\begin{array}{c}\text { Value } \\
\text { (Rs Lakh) }\end{array}$ \\
\hline Coir fibre & 9 & 1.89 & 12 & 4.59 \\
Coir yarn & 13,648 & $2,637.19$ & 11,442 & $1,966.18$ \\
Coir mats & 15,945 & $6,891.96$ & 13,787 & $5,082.37$ \\
Coir matting & 5,263 & $2,318.05$ & 4577 & $1,775.89$ \\
Coir rugs \& Carpets Coir & 1,636 & 839.26 & 1327 & 573.89 \\
Other sorts & 343 & 36.96 & 94 & 16.89 \\
Coir rope & 351 & 63.12 & 68 & 13.81 \\
Curled coir & 600 & 49.33 & 935 & 90.15 \\
Rubberized coir & 156 & 98.99 & 112 & 71.54 \\
\hline Total & 37,951 & $12,936.75$ & 32,354 & $9,595.31$ \\
\hline
\end{tabular}

